\title{
Northumbria University
}

\section{Tony Williams}

\section{Grettir in Sheffield: Rewriting Icelandic saga as a contemporary novel}

\begin{abstract}
My novel NUTCASE (2017) rewrites the medieval Icelandic Saga of Grettir the Strong as the story of Aidan, a young man growing up in Sheffield in the UK in the 1990 s and early 2000s. It is also an attempt to reproduce the style and structure of an Íslendingasaga [saga of Icelanders] in a contemporary novel. This article sets out the project's rationale, surveys other relevant novel engagements with saga, and articulates my research process with particular focus on violence, style and voice, the monstrous, and gender. The project represents the first attempt by a novelist writing in English to adopt wholesale the style and structure of the family sagas, and the first English rewriting of a specific saga into a contemporary setting. This article provides a reflective account of that rewriting process, and in doing so it provides a model for other writers to learn from the forms and techniques of other medieval literatures. It argues that treating medieval texts not merely as sources to be plundered for content but as practical paradigms we can learn from enables our contemporary practice to be expanded and reinvigorated by the writing practices of the past.
\end{abstract}

Keywords: novel, saga, rewriting, realism, violence

\section{Introduction}

My novel NUTCASE (2017) tells the story of Aidan, a young man growing up in Sheffield in the UK in the 1990s and early 2000s. But the contemporary setting may obscure its medieval origins: NUTCASE is actually a rewriting of the Icelandic text Grettis saga Ásmundarsonar [The Saga of Grettir the Strong] (1997) [1]. Whereas most modern engagements with saga appropriate 'Viking' content, NUTCASE attempts to reproduce the style and structure of an Íslendingasaga [saga of Icelanders] in a novel with a contemporary setting. My research takes as its inspiration Jane Smiley's comment that there is 'plenty for an aspiring novelist to learn from the sagas' (Smiley 2000: xiii; see also Smiley 1999). In this article I set out the project's rationale, survey other relevant novel engagements with saga, and articulate my own research process with particular focus on violence, style and voice, the monstrous, and gender. By providing a reflective account of the rewriting project and process, I set out a model for other writers to learn from the forms and techniques of other medieval literatures. Rewriting a medieval text into a modern setting means that 'two different cultures and two different historical contexts enter into a dialogue' (Bampi 2005: 210), and the nature of that dialogue will vary from text to text and culture to culture. Rather than listing some specific 
techniques or tropes that modern writers can learn from the sagas, I hope to demonstrate that engaging closely with a medieval text can help not only to shape a text but also to produce a clearer understanding of a writer's own society. By treating medieval texts not merely as sources to be plundered for content but as practical paradigms we can learn from enables our contemporary practice to be expanded and reinvigorated by the writing practices of the past.

The Íslendingasögur, referred to in English as the 'sagas of Icelanders', or sometimes as 'family sagas', are prose narratives about the lives of wealthy farmers living in Iceland in the tenth and eleventh centuries, now existing in manuscripts dating back as far as the thirteenth and fourteenth centuries. The Íslendingasaga is a subgenre of the Icelandic saga, and though scholarly interest has since widened to cover other subgenres more deeply, during the late nineteenth and twentieth centuries interest in Icelandic sagas among scholars, general readers and writers was focused on the Íslendingasögur. One reason for this may be that this subgenre most resembles the realist novel, the dominant literary form of the period, so that readers were able to engage with themes, modes and styles they were familiar with (Clunies Ross 2002: 445). This in turn might have led to a skewed modern perception of the sagas as a predominantly realist form, rather than what Margaret Clunies Ross describes as the 'mixed modality' of realist and fantastic elements (2002: 445; a subject I come back to below). On the other hand, it is my own experience as a reader that the saga does not map directly on to the novel (see also Vésteinn 1998: 235; Tulinius 2013: passim). The typical saga is somehow both gripping and tedious, vivid and fugitive. It is the sense of reading a narrative that is both familiar and strange that makes the saga such a fascinating, accessible and yet rebarbative text for a modern reader. That is what provides the impetus for my research: the opportunity to challenge and enrich the novel by drawing on a form of prose narrative that intersects and diverges from it in interesting ways.

\section{Saga realism, style and structure}

The notion that the family saga resembles the realist novel originates partly in a perceived similarity of subject matter. Both are concerned with the daily life and personal relationships of relatively ordinary people (Byock 1984: 160; Kári 2009: 14; for complications of this view see Ármann 2011: 31; Vésteinn 1998: 24-25). The sagas depict 'what we might call the realia of saga society', that is, 'the operation of medieval Icelandic political and social institutions [and] the details of everyday life' (Clunies Ross 1997: 446). Both sagas and novels depict 'men and women who live in communities of people who are more or less their equals, whose personal qualities determine the outcome of their intentions and whose stories constitute models of social and psychological behaviour' (Smiley 2000: ix$\mathrm{x})$.

As well as providing models of behaviour which imply saga-age society's values, the saga narratives themselves reflect the structure and conditions of the society they depict. The ubiquitous depiction of feud conflicts in sagas reflects the centrality of feud as a legal or quasi-legal process in medieval Iceland (Byock 1982: 1-2, 24-46; Byock 1984: 166). Violence in the sagas is not always aberrant: it can be licensed as a perfectly normal stage in the processing of legal conflicts. (Crucial here is the fact that medieval Iceland possessed judicial and legislative arms of government, but no executive arm, so participants in disputes were responsible for making sure that their own legal judgements were carried out 
(Vésteinn 1998: 26; Helgi 2007: 139-141; Byock 1982: 27; Andersson \& Miller 1989: 7-8, 22).) Violence in the Íslendingasögur, then, does not function as a breakdown in the social order (as it arguably does in, say, the modern crime novel). It may serve an implicit critique, but feud violence per se is a legitimate part of the social order rather than an aberration. In the sense that their violence is generated by the normal operation of social institutions, 'the sagas depict, often in considerable detail, the inner workings of the old society, almost as if displaying the workings of a clock with its backplate removed' (Vésteinn 1998: 22). Although Vésteinn insists that the sagas of Icelanders are 'not novels, not even historical novels' (235), he argues that the two subgenres share this specific vision of realism:

If we are correct in believing that in some Íslendingasögur we can identify broad social forces reflected in the fates of individuals, we may conclude that the authors of these sagas may have set themselves priorities very similar to those recognized as important by historical novelists centuries later. (1998: 234; see also Harris 1986: passim)

As well as having similarities of subject matter and function, Íslendingasögur and the novel resemble each other stylistically. The use of a 'relatively... simple vocabulary' (Thórir 2007: 365), and more generally of a direct and immediate reporting of action, gives sagas an immediacy which resembles that of modern prose fiction. Similarly direct speech is used heavily, often to express thoughts (Vésteinn 1998: 113).

But there are also stylistic differences. Most significant here are the laconic approach to dialogue and narration (Thórir 2007: 365), and the relative lack of descriptive colour: '[s]aga technique is to tell the story rather than to explain it' (Byock 2004: 309). The result is that novel-readers usually find sagas fast-paced and extremely spare, which can be discombobulating.

Alongside this laconic narration, the saga style is 'objective' in the sense that the reader is given little or no direct access to characters' thoughts, motives or emotions. The narration is limited to reporting what could have been witnessed by third parties (Thórir 2007: 366; Vésteinn 1998: 101). Although 'characters' personal and emotional lives are unashamedly the focal point of the narrative' (Vésteinn 1998: 233), these are only revealed through dialogue and action. This reticence about characters' interiority represents a major divergence from the modern novel in many of its forms, and novel engagements with saga typically vary from their sources precisely by rescinding this restraint and exploring individuals' subjectivity (see below).

The following fairly typical short passage from Grettis saga illustrates the style's fast pace, laconic approach and lack of focus on interior states:

A little later Thorkel made ready to go to the Althing and set off with sixty men, for all the farmers who supported him went with him. He called at Bjarg, and Grettir joined him there. They went south across Tvidægra Moor, and they rode fast across the high country, since the grazing was poor there, and then they came down to the settled district beyond. When they rode down to Fljotstongue, they thought it was time to sleep, so they unbridled their horses and let them graze with their saddles on. The men slept until late in the day, and when they woke up they started 
looking for their horses in all directions - some of them had been rolling in the ground. Grettir was the last to find his horse, and he found him with the saddle under his belly and the food-bag gone.

(Grettir's saga 1974: 29)

It is this combination of stylistic features, mapping the saga imperfectly on to the novel, which makes reading sagas an uncanny experience for the novel-reader. There is no doubt that the sagas represent a literature of global importance. And yet, whereas engagement with Greek and Latin literature has since the early modern period included imitation and appropriation of genre, form and style, writerly engagements with saga have tended to ignore their value as technical models, drawing instead on subject matter. For example, '[Sir Walter] Scott's knowledge of old Icelandic literature is well known ... but he did not imitate the narrative techniques of old sagas in his own novels' (Vésteinn 1998: 233; see also D'Arcy \& Wolf 1987). In this project I reverse this position, taking on saga style and structure but abandoning the medieval setting and subject matter.

\section{Novel engagements with saga}

Saga literature has been a fertile source for modern and contemporary culture, from prose fiction and film to cartoons, graphic novels and heavy metal (Jón Karl 2017: passim). There is not space here to trace the modern novel's engagements with saga in any detail. But such engagements typically fall into two main categories. The modern fantasy novel emerged in part through engagement with saga (particularly the fornaldarsögur [legendary sagas]) in the work of JRR Tolkein and William Morris, and lies outside the scope of this paper (see, for example, Phelpstead 2008; Burns 1991; St Clair 1995). Novelists rewriting or drawing on the (supposedly more 'realist') Íslendingasögur have tended to be historical novelists, appropriating saga settings, subject matter and iconography and 'pouring' that material into the 'mould' of a modern form. This choice of genre should not be a surprise: the saga age is in the past, so it invites a historical treatment, and, as we have seen, both historical novels and Íslendingasögur are concerned with 'broad social forces reflected in the fates of individuals' (Vésteinn 1998: 234). But their stylistic approach is different. Typically, historical novels tend to be longer and slower paced, with much more descriptive detail, and they allow access to characters' unspoken thoughts and feelings. In broad terms, they appropriate saga subject matter but their style is at best inflected by the medieval form.

Dorothy James Roberts's Fire in the Ice (1961) draws on Laxdola saga and Njáls saga, arguably the two most famous sagas of Icelanders. Roberts's protagonist Hallgerda is the Hallgerdur Höskuldsdóttir who plays significant roles in both. The rewriting of these texts around a female central character moves reader attention away from male-dominated concerns of wealth and societal honour, towards Hallgerda's felt experience of a woman's life in that society. This shift is reflected stylistically. The sagas' 'impersonal and understated narrative style' (Jón Karl 2005: 189) is replaced by a third-person limited viewpoint focalised through Hallgerda. This allows her subjectivity to emerge as the primary interest of the novel and as the leading driver of its plot (187). Meanwhile the inclusion of large amounts of historical detail makes the saga world accessible to a modern audience (187). 
Jane Smiley's The Greenlanders (1988) depicts a Norse community in the failing Greenland settlements, some time after the saga age itself. Like Fire in the Ice, it uses a female character, Margret Asgeirsdottir, as its main protagonist, and this novel can be also viewed as an attempt to discover a subjectivity lying behind saga narratives, and in particular a female lived experience which the sagas largely ignore. Like Roberts, Smiley allows access to protagonists' interiority (see, for example, Margret's meditations on her adultery in Smiley 1988: 123; see also Nakadate 1999: 112). But such access is intermittent (Nakadate 1999: 128-130), surrounded by long passages of a more restrained, 'objective' narration, and this illustrates a wider tendency on Smiley's part to mix the narrative techniques of medieval saga and of the modern historical novel. There are 'emotionless declarative sentences' reporting action (Nakadate 1999: 111), but also passages of vivid description, and the dialogue though terse in tone is often extended beyond the saga norm (eg Smiley 1988: 370-372).

Smiley's novel provides an original narrative in a saga-inspired setting. Roberts' novel however adapts two specific texts, Laxdoela saga and Njáls saga, rewriting them from a specific character's point of view. There are a number of other novels which adapt specific sagas, engaging more or less closely with saga style, but whose approaches are for one reason or another not quite pertinent to my own project. George Mackay Brown's novel Magnus, a treatment of Orkneyinga saga, uses a stylistic and asynchronous collage which draws implicitly on the sagas' mixed modality and prosimetricality; Maria Dahvana Headley's The Mere Wife rewrites Beowulf in American suburbia, a stylistically complex updating of a different medieval literature; and Jackson Crawford's extraordinary Tattúínárdǿla saga (2010) rewrites the Star Wars franchise as an Icelandic saga in both Old Norse and English translation.

A number of modern Scandinavian novelists have drawn on Icelandic saga (Tulinius 2005: passim; Hall 2018: 354-355). Typically, though, they have adapted saga content to the conventions of a modern form (Hall 2017: 30), or allowed the narrative voice to explore characters' interiority (Tulinius 2005: 197, 203). These formal changes are one reason such rewritings struggle 'to get beyond an individualistic account' (Hall 2018: 365) to achieve the exploration of social structures and forces which characterise the sagas (Hall 2018: 355).

Even in Iceland, then, novelists have not drawn extensively on Íslendingasögur as stylistic or structural models. One exception is Halldor Laxness's Gerpla (1952), published most recently in English translation as Wayward Heroes (2016), a retelling of Fóstbroedra saga [The Saga of the Sworn Brothers] which retains its historical setting as well as a saga-like terseness and objectivity. Gerpla's modern aspect lies in its interpolation of a droll antiheroic irony, which draws on and deepens the sagas' tendency to ironic dialogue.

The writer who has pursued the most sustained and systematic engagement with saga style is the Swedish novelist Per Olof Sundman (Bampi 2005: 211; McGregor 1993: 1-50; Stendhal 1981: 251). He draws on a number of saga techniques: 'the economy of expression, the straightforward presentation of characters and events, the laconic terseness of the dialogue, in which the short utterances often have a pregnant fateful weight or take the form of mordant repartee' (Warme 1984: 180). Perhaps the most noticeable feature is the use of 'objective' narration, in which only exterior events are related (Stendhal 1981: 251-252; Sundman 1970: 185-186, 190; Warme 1984: 176), although this is 
complicated and softened by his use of first person in contrast to the third-person approach of the sagas (eg Sundman 1970).

Sundman's last novel Berättelsen om Såm [The Story of Sam] (1977) comes closest to my present project. It retells Hrafnkels saga Freysgoda [The Saga of Hrafnkel Frey's Godi] in a modernised setting while approximating saga style (McGregor 1993: v-vi; Bampi 2005: passim). McGregor (1993: 197-246) and Bampi (2005: passim) both provide detailed analyses of the relationship between the novel and its source. (In this discussion I rely heavily on McGregor, Bampi and Warme, since the novel has not been translated into English.) Sundman maintains saga techniques such as the use of proverbs and laconic dialogue (McGregor 1993: 229-230), mixing of tenses (233) and foreshadowing (233-234), and makes allusion to a number of sagas and Norse sources $(227,231-232)$. The wider community are allowed to voice their opinions on events (234). However, the novel also varies from saga style, for example by containing descriptive passages (McGregor 1993: 223-225), in its only intermittent objectivity and in its use of authorial commentary, direct thought, free indirect thought and extensive dialogue (235-237).

This imperfect stylistic mapping may be a consequence of the rewriting project. Bampi argues that the "choice of retelling the story by setting it in the present forces the writer to adapt or substantially modify some central features of the saga' (Bampi 2005: 215) in order to make sense of it in 'a new cultural and historical context' (221). As we shall see below, in order to make a coherent novel of my own rewriting I was also led to soften and vary some aspects of saga style and structure. But it is worth examining in more detail Sundman's programme of rewriting, since in important ways it differs from my own.

Berättelsen om Såm is called variously an 'interpretation of the old saga' which 'takes place in Iceland in modern times' (Stendhal 1981: 256) and a 'retelling in modern dress' (McGregor 1993: v). The novel's dustjacket declares that 'The conflict between mighty men and poor farmers is a timeless conflict - but how to translate it to our times' (quoted in Stendhal 1981: 256; see also Bampi 2005: 214). This imputation of universality lies in tension with the widely held idea, discussed above, that saga realism consists in its ability to depict the workings and consequences of historically specific social structures, for example the legal system which led to feud violence as a form of dispute resolution. The conflicts depicted in sagas are precisely not timeless but illustrate how social relationships are historically determined.

In my own rewriting project, I was interested not in depicting unchanged a 'timeless' conflict 'in modern dress', but in discovering how such a conflict modulates to produce new meanings once it is translated into a new social and historical context. Sundman's remark that 'I wanted to let the action be set in our time with for example cars instead of horses. Thought that the moral problems that the saga deals with would be lost behind round shields, shining helmets and sharp swords' (qtd in McGregor 1993: 199) suggests that his intention was to find a more neutral setting for what he considered a historically neutral story. McGregor adds that '[Olof] Palme said that [Sundman] hadn't really set the novel in the present, but rather he had borrowed various things from the present' (319). The setting is indeterminate in both period ('the novel takes place in the present, but not entirely in the present' (Sundman qtd in McGregor 1993: 319)) and place ('My landscape is Icelandic but it is not Iceland' (qtd in McGregor 1993: 207; Bampi 2005: 215)). Rather than a 'retelling in modern dress', the novel contains elements 
from both the present and the past, so that 'the temporal setting is intentionally depicted as swinging between two opposite poles in order to stress the translatability of some major features of the past into the present' (Bampi 2005: 217). The rewriting thus becomes a 'point of encounter' (221) in which the past and the present can enter into a dialogue (210). While this may be true, the uncoupling of the saga narrative from a specific historical setting undermines (or at least complicates) any claim it might make to depict the reality of social forces and structures. In my own rewriting I did not want to mix the past and the present but to transplant the saga narrative wholly into a modern setting, so that it might function in some way similarly to the original text.

\section{Rewriting Grettis saga}

In writing my own saga novel, I wanted to reproduce as far as possible the style and structure of the sagas. I wanted to do so for two reasons: to reproduce some of the strangeness I feel when reading the sagas, and to approximate their way of representing the social reality of their setting. Imitating that realist function might in turn help me to understand my own society in new ways. What follows is an account of the process of rewriting, the decisions I made in order to reproduce certain saga features, and to jettison other features when they did not serve my purpose. It is necessarily an account of compromise.

Initially I tried to isolate key stylistic features such as objectivity, fast pace, and laconic third-person narration, and reproduce them in a new narrative. These early experiments had a tendency to drift back into a more recognisable novelistic mode (eg I would gradually find the pace slowing and the narrative becoming more detailed). It also became clear that cherrypicking stylistic elements was a superficial way of engaging with saga-writing practice. As a mature genre the Íslendingasögur hold style, structure, mode and content in a particular relation, and if I were to capture their effects - and the claim to realism - effectively, then I would need to find a way of preserving as many of those elements as possible in the translation to a contemporary setting.

I decided to choose a specific saga and rewrite it into a contemporary setting and idiom. This would have the obvious advantage that a plot and structure suitable to the saga form were more or less ready-made; my task would be to make that plot work in the modernised setting, and more specifically in the new historical and social context of that setting. But this also raised questions about what happens when a story is translated from one cultural and social context to another.

The most pressing problem I faced was to find a way to accommodate violence. The Íslendingasögur are full of conflict and killing, and this reflects the structure of saga-age society: in the absence of an executive arm of government, violence was a legitimate and accepted tool for enforcing legal judgements. In this sense the sagas are realist, reflecting the structures of the society they depict. But in the contemporary UK where my novel was to be set, violence plays no such legal role, and so outbreaks of violence are handled differently, as aberrations. In particular, violent acts are likely to be dealt with by the police and judicial systems in a way which prevents them motivating and sustaining a narrative quite as they do in sagas. I did not want my rewriting to degrade a realist text into a largely meaningless pornography of violence, but to find an equivalent narrative that might shed light on the role and position of violence in contemporary society. 
The solution lay partly in the choice of source text. I decided that translating one of the so-called 'outlaw sagas' would mean I was dealing with a protagonist whose violent acts are not tolerated as quasi-legal but condemned as illegal. It is in the figure of the outlaw that saga violence thus comes closest to contemporary violence: in both cases it is an aberration. The saga I chose to rewrite is Grettis saga Ásmundarsonar or The Saga of Grettir the Strong, a relatively late saga (possibly written around 1400) whose 'style, form and narrative technique, characterization and attitude to literary tradition prefigure the birth of the novel' (Scudder \& Thorsson 2005: ix). The saga describes the life of the Grettir Asmundarsson, a man whose physical prowess and aggression position him ambivalently as hero and villain in the community, until he is outlawed and lives the rest of his life as a bandit and fugitive.

I imagined Grettir as Aidan, a young man growing up in a disadvantaged community on an estate in Sheffield, UK. Although I would not want to suggest that violence is more prevalent or more accepted in such a community, I did feel that disenfranchisement might make its members less likely to appeal to a police and criminal justice system they distrust when faced with violent acts. In this way the saga narrative might be enacted partly outside such systems, enabling a feudlike series of conflicts to develop. Meanwhile, the same disenfranchisement might lead members of the community to laud a violent criminal as a hero, either by vigilante activity which they perceived as more effective than the police, or by renegade activity directed against the authorities. (The 2010 Raoul Moat case had demonstrated the highly polarised and often positive responses that violent male criminals can provoke in the public (McFarlane 2013: 330-332).) Even with this approach, it was still necessary to tone down the violence of the saga, sometimes by missing out violent episodes entirely and sometimes by reducing killings to non-fatal acts. I had to truncate chains of vengeance in order to reflect the fact that violence has a more marginal and more aberrant status in modern UK than in saga-age society. Even in reduced quantities, it is striking how much violence there is in the novel; I was surprised as it unfolded how brutal the narrative felt. This made me reflect on our reading of violence in the sagas. It may be that the exotic or othered setting allows modern readers to swallow quite cheerfully a level of violence which, translated into a contemporary setting, strikes them as horrific.

In translating the saga into its new setting I faced a number of other challenges. I had to find a suitable narrative voice, and I had to find ways of staying faithful to the saga in two sometimes conflicting ways: by rewriting Grettis saga in a way which reproduced its plot, while also working on its own terms as a novel; and by maintaining as far as possible in doing so the saga's structural, stylistic and technical features. In the rest of this article I set out how I approached the issue of voice, and then assess the issue of fidelity as it played out in some key areas.

In order to reproduce the effects of the saga in its new setting I had to find a narrative voice in which saga style could be approximated. Whereas Per Olof Sundman's approach seems to have been to preserve as far as possible a medieval language (McGregor 1993: 232), I wanted to find a modern language in which the key technical features could be reproduced. The most important of these features were brevity and objective narration. The latter consists not just in the focus on reporting external events, but also the way that accounts of contested events or interpretations of events are couched in terms of the explanations which members of the community put forward ('All who heard about this deed were greatly impressed by it, and said that no man in the entire country was Grettir Asmundarson's equal in strength' (Grettir's saga 1974: 79)). The 'voice of the 
countryside' purports to express the 'anonymous opinion of the people in the region' (McGregor 1993: 234), and in this way promotes the idea that the sagas report a narrative which is in some way shared by a community. The saga-writer's own identity is effaced, and even the implied third-person narrator remains elusive, a supposedly neutral reporter of the actions and speech of others. My solution therefore was to write the novel in a highly demotic, communal voice, inflected with a local idiolect but not attached to a specific individual. In a sense the novel became a form of gossip, an idea reinforced by my recasting the "voice of the countryside' as a Greek chorus in the local taxi office:

Irene who manned the phones at the taxi office said the sooner he ended up dead in a ditch the more peaceful life would be for everyone else. But Gemma, who had only been there six weeks and had all the drivers eating out of her hand, said it was young men like Aidan that made her proud to be British. (Williams 2017: 49)

Within this broad solution I made a number of stylistic choices, sometimes bringing me closer to the saga and sometimes taking me further away. For example, like Sundman I co-opted the saga's mixing of tenses to produce a rather unsaga-like foregrounding device at a dramatic moment (McGregor 1993: 233; Williams 2017: 30-31). But I jettisoned completely the saga's prosimetrical element; like many sagas, Grettis saga contains a number of embedded verses, usually as a form of dialogue (Scudder \& Thorsson 2005: xiv), but I did not see a way to reproduce that in the novel in a way which fit with the demotic narrative voice. Meanwhile, although in the main I keep the focus on external events, the objective narration does slip at times: for example, 'On the way home Aidan threw the orange over someone's garden wall, and he was angry and glad at the same time' (Williams 2017: 63; italics added); but note that the saga also allows itself such small-scale breaches: 'Onund and Asmund, who heard this, assumed that Asgrim was dead, and they thought there was nothing they could do about it' (Grettir's saga 1974: 13; italics added).

With a new setting and voice in place, the rewriting approach meant that I was able to break down the task, at least initially, by considering the function and effects of a passage in the original saga when writing the equivalent passage in my own. Working from a source text provided the scaffolding of an underlying narrative, even if I had increasingly to consider the new narrative that was emerging on its own terms. In its early stages NUTCASE maps its events relatively closely on to those of Grettis saga. For example, in chapter 16 of the saga (qtd in part above) Grettir goes with a man called Thorkel and a group of men to the Althing [Iceland's parliament] (Grettir's saga 1974: 29-31). In NUTCASE this is adapted into a holiday to Amsterdam (the following passage also illustrates the narrative voice):

There was a group of twelve of them. 'Like the fucking apostles,' said Arshan, but they all gave him blank looks. They got a National Express to Newcastle then piled on to the ferry. Arshan had said to bring some cans so they didn't have to pay the ferry prices. Aidan had a bag of Carlings from Londis, a couple of packets of ready salted and a steak bake.

They sat in the lounge area and drank for a bit, then headed off on deck, some to chuck up and the others to laugh at them and throw sandwiches for the birds. Aidan came inside again and played for 
a while on an old Virtua Cop 3 console, trying to impress these posh girls from Harrogate, but then their teacher turned up. So he went back to the seats where his stuff was, but all his cans had gone. There was just a few crisps trodden into the carpet.

(Williams 2017: 22)

As the novel goes on, the mapping of scenes and structures becomes less and less direct. Like Sundman I was obliged to make a number of changes to plot (McGregor 1993: 215ff). This is partly because the analogues I find in the early scenes are imperfect, so as the narrative goes on, a tension emerges between fidelity to the saga and fidelity to the story which is emerging from the contemporary materials. Although the novel stays broadly faithful to Grettir's story, in order to be convincing on its own terms, a looser and looser interpretation becomes necessary. For example, in the saga Grettir's younger brother Illugi is with him for the final stand on the isle of Drangey (Grettir's saga 1974: 163-169). In the novel, the younger brother falls from a tower block, precipitating a climactic sequence of events which he does not appear in (Williams 2017: 220-225). I made this change partly because I felt Aidan needed that trauma as an additional motivation at that point, and partly because Aidan's final series of acts really only made sense emotionally and culturally if he was alone.

This kind of variation shows that rewriting from one cultural context to another is not a direct mapping. It can't be, since the 'cultural and ideological differences' between the two contexts (Francis 2018: 312) make different narratives intelligible. These differences in turn demanded changes which could be relatively trivial or could be more significant, bearing on the whole mode of the novel. An example of the trivial kind is the topping and tailing the novel performs on the saga. I omitted the first twelve chapters of the saga as these deal with earlier generations of Grettir's family, and similarly ended the novel with Aidan's death and its immediate aftermath, omitting the final chapters of the saga which deal with Grettir's brother Thorstein's visit to Constantinople (Grettir's saga 1974: 3$21 ; 173-187)$. Scudder \& Thorsson argue that the saga 'calls to mind a triptych with two wings that illuminate and enhance the magnificent centrepiece, but which may be removed without damaging it' (2005: xxi). I am not equipped to say whether that is the case (and see Fox \& Hermann 1974: viii for an opposing view), but certainly the prologue and epilogue felt extraneous to the main action of the novel, so I made the decision to silently omit them. More significant than this topping and tailing were two challenges that played major roles in shaping the novel, one literary and one cultural: the saga's use of fantastical elements, and its treatment of gender.

Grettis saga, like most sagas of Icelanders, uses what Clunies Ross has called a mixed modality, in which the realistic and fantastic modes are used interchangeably and without any attempt to resolve the overall claims which the text makes about the reality or otherwise of its materials (Clunies Ross 1998: 4251; 2002: 445). The narrative's treatment of Iceland's social institutions and their effects on individual lives - its so-called realism - exists alongside encounters with 'ancestral heroes, berserks, trolls, giants and so forth' (Clunies Ross 2002: 449). Modern readers have typically been puzzled by, or simply ignored, the fantastic in sagas (Clunies Ross 2002: 445), as if non-realistic elements were simply 'extraneous' to the 'classical' saga mode and function (Clunies Ross 1998: 80; see also Tulinius 2013: 20). There was a strong case for taking a similar approach in my rewriting. NUTCASE was going to challenge modern readers with its fast pace and lack of interiority, and I felt that including supernatural elements 
such as ghosts and trolls was likely to be a bridge too far. Fantastic elements might be for me, as 'heathenism' was for Sundman's rewriting, something 'which can hardly find a full equivalent in the present, and whose unaltered "translation" into modern times would bring about an effect of estrangement' (Bampi 2005: 215). Initially I tried to solve this difficulty by introducing not supernatural elements but their tonal equivalents. For example, instead of Grettir's stay with the half-troll Thórir and his daughters (Grettir's saga 1974: 129-130), I had Aidan stay with a survivalist father and daughter who live off-grid in the Peak District. But this introduced a farcical flavour and did not gel with the rest of the narrative. The mixed tonality proved just as challenging to a modern ear as the sagas' mixed modality.

However, I could not simply jettison such elements entirely. Clunies Ross argues that 'the fantastic mode in the sagas frequently occurs precisely where there is some uncertainty as to the nature of reality, or where the social norms of the culture are subverted' (2002: 449). This view accords with readings of fantastic literature as 'open[ing] up ... on to that which lies outside the law, that which is outside dominant value systems' (Jackson 1981: 4). The fantastic 'disturbs us by dislodging us from our settled sense of reality, and tries to engage our emotions on behalf of this new version of the real' (Hume 1984: 56). In Grettis saga, it is no coincidence that the supernatural is involved in the pivotal episode of the narrative, Grettir's fight with the ghost Glámr (Grettir's saga 1974: 76-80; in a saga context 'ghost' implies a corporeal existence, not merely an ethereal one). Grettir travels to the farm which Glámr haunts and fights him. Grettir is victorious, but before dying Glámr lays a threefold curse on him: he will never reach his true potential for strength; from now on his deeds will bring him not fame but 'outlawry ... ill luck and misfortune'; and 'you will always see before you these eyes of mine, and they will make your solitude unbearable, and this shall drag you to your death' (79). The supernatural encounter thus provides a concrete narrative motor for Grettir's transition from hero to outlaw, and for the saga's dramatisation of the struggle between pagan warrior and Christian settler values. The fantastic is deployed just at a point where conflicting value systems generate a fault in sagaage reality.

In rewriting Grettis saga this was one fantastical element I could not simply elide. It was clear that the fight with Glámr had to be reproduced in some form, providing both the high point of Aidan's heroism and the beginning of his outlawry. However, I felt that the supernatural simply could not play such a role in the novel: for saga characters, the existence of trolls and witchcraft possessed a credibility (Clunies Ross 1998: 14, 42) very different from their modern incarnations in European cultures. A modern reader would likely read as mere entertainment what may for a saga-age audience have constituted a troublingly real threat. What I needed to replace Glámr was not a stage-troll but a figure able to produce revulsion and fear in a modern reader, a contemporary monster that could play an analogous narrative role. I found it in the figure of the paedophile Gary, whom Aidan confronts and kills (Williams 2017: 63-72). The paedophile's cultural positioning as beyond the pale meant that Aidan could kill him with relative impunity and even be praised for it; meanwhile I reproduced Glámr's curse by having the episode lead to Aidan suffering from PTSD. Thus, while I was not able to reproduce the mixed modality of Íslendingasögur in the novel, finding a narrative equivalent to Glámr enabled the saga's narrative structure to endure and illuminated the values and anxieties both of saga-age Iceland and of the contemporary UK. 
Finally, I would like to turn to a difference in cultural context which led to several changes in the rewriting: the treatment of gender. The sagas are male-dominated in the sense that most (but not all) of the protagonists, antagonists and other active characters are male, and in the sense that they depict a patriarchal society. Like Sundman (McGregor 1993: 208; Bampi 2005: 218), I tried to address this in the novel by increasing the number of significant female characters and giving women more active roles. The most striking example of this is my treatment of the 'sworn brothers' Thorgeirr and Thormódr. These two men are the focus of a different saga, Fóstbroedra saga [The Saga of the Sworn Brothers], but they also appear intermittently in Grettis saga as rival outlaws with whom Grettir maintains a guarded neutrality (1974: 56-60, 104-107). In NUTCASE the sworn brothers became Shelley Turner and Mark Crabbe (Williams 2017: 44-48, 97-103, 204205). By making one of the brothers a woman, I went some way to redressing the gender balance of the novel and increasing female agency, using a Bonnie-andClyde trope to make sense of the medieval sworn bond. It is important to note that this is not a case of moving from a gender-imbalanced medieval culture to a gender-neutral contemporary one. Violence remains gendered, and I have Shelley remark that 'when a man was hard everyone wanted to be his friend, but if a fit young woman was they said she was a sicko' (45).

As with the treatment of fantastic elements, difficulties with gender were focused on a specific scene in the saga. Whereas the fight with Glámr is obviously pivotal, the scene which illustrates the changed cultural context of gender, the episode involving Grettir and the maidservant in chapter 75 (Grettis saga 1974: 154-155), is notable precisely because it does not play a crucial role in the original narrative.

Grettir is a guest at a farm, and in the morning is discovered in the hall by the farmer's daughter and a maidservant, asleep and naked. The maidservant remarks that Grettir's penis is small, and keeps 'going over and peeping at him, and then running back to the farmer's daughter and bursting out laughing' (Grettis saga 1974: 154). Grettir wakes up, speaks some verses to the effect that his penis can get bigger, and then initiates sex (155). The circumstances are ambiguous. The Fox \& Hermann translation runs: 'The maid kept crying out, but in the end, before they parted, she had stopped taunting him' (155). To a modern reader it is conspicuous that the saga does not specify whether the sex is consensual. There is a clear (but not conclusive) case for viewing the episode as an instance of rape (Phelpstead 2007: 430; Ljungqvist 2015: 435-436). Perhaps surprisingly, the saga says nothing more about the incident: neither characters nor narrator pursue it, and it has no consequences in the story. In order to understand the narrative context and the challenges of rewriting the scene for NUTCASE, a short discussion of sex and gender in the sagas is necessary.

In saga-age Iceland, rape may not have constituted an offence distinct from fornication and/or abduction (Ljungqvist 2015: 433-434), and in any case was understood primarily as an honour crime against the woman's male relatives rather than against her (Ljungqvist 2015: 435; Jochens 1995: 32; see also Francis 2018: 312). The crime's legal status and consequences thus depended on the woman's social standing and her family connections. Notice that the farmer's daughter, protected by such factors, withdraws from the hall unharmed (Grettir's saga 1974: 155), perhaps implying a more seemly attitude associated with her social position and/or that Grettir knows which woman can be targeted more easily - and indeed, according to the law at the time, legitimately. Female servants, like slaves, are likely to have been expected to be sexually available for their masters, employers and guests (Jochens 35). Thus from a strictly legal point of view the maidservant's 
consent would not be required, and the question of whether Grettir rapes her does not arise. This is why the incident has no consequences in the saga: in a narrative structured by feuds generated under the Icelandic legal system, the maidservant lacks the social status and the powerful male relatives that would be needed to make the rape a narrative motor. Instead it functions as a dead end, a passing incident which might illuminate Grettir's character but plays no role in the chain of feuding which constitutes his story.

It was obvious that my rewriting could not treat the episode in the same way [2]. Again, this was not about comparing a reprehensible medieval society with an ideal contemporary one. Certainly, violence against women in the present is often under-reported, tolerated, hidden and ignored, and the notion of a sexual assault going unpunished would not be outlandish. However, while characters in the novel might ignore an apparent rape, the narrative itself could not do so. The different legal and cultural status of sexual violence in contemporary society demanded a more sustained treatment of the episode and its consequences; even if those consequences were to be minimal, the novel would have to address that fact. The episode expands from two pages in the saga (Grettir's saga 1974: 154-155) to eleven in the novel (Williams 2017: 147-158), and now constitutes a major plot element.

I also had to negotiate the tonal and narrative difficulties involved in depicting a crime which occupies a particularly reviled position in contemporary UK culture. Making Aidan unambiguously guilty of rape would decisively shift the reader's sympathy against him, and lead to this storyline eclipsing the existing main narrative. Conversely, I did not want to manipulate sympathy in the opposite direction by having Aidan wrongfully accused of rape, nor evade the issue by simply making the sex consensual. In short, decisively depicting Aidan as either guilty or innocent did not fit with my project of reproducing the narratorial neutrality of saga narration. Although the apparent ambiguity of Grettir's encounter with the maidservant lies, as we have seen, in the different legal and cultural context of saga-age society, nevertheless to this modern reader it embodies the virtues of objective narration for which the sagas are praised. Per Olof Sundman writes of the saga author Snorri Sturluson that 'He hands over his sagas as a sort of reality to his listeners/readers. It is they themselves, each according to his own ability, who have to complete what is narrated and give it a content - in the same way in which they judge and evaluate what they are exposed to in "real" life' (qtd in McGregor 1993: 3). Sundman's own 'ideal of presenting characters and situations that are open to multiple interpretations' in order to 'enlist' the reader in an 'investigation' (Warme 1984: 176) also describes my approach to the rape scene. Rather than leaving out crucial details that would clarify the question of Aidan's guilt, I tried to depict clearly a series of actions which, unambiguous in themselves, would be subject to disagreement over their legal and ethical status. In other words, I tried to construct events so that both characters in the novel and readers outside it could honestly disagree over whether or not rape had been committed (though note here the strain on a supposedly neutral narrative voice which is in fact partly focalised through Aidan):

'Jesus,' said Aidan after this teasing had gone on for a while. 'You seem very interested in it. Why don't you come upstairs for an hour and then we'll see how small you think it is.'

And Melody said, 'Yeah, get a room.' At first she had laughed along with Jojo but now she wasn't laughing. Jojo was like a 
terrier with a rat, and it was all getting a bit much. Higgsy was going out to pick up some beer and a quarter of skunk, and Melody said she'd go with him. She was hoping to pick up some extras with the skunk and let big brother foot the bill.

After they had gone it was just Aidan and Jojo, and she kept on going on about the size of his cock, 'You poor bastard,' and so on.

'You're a real pain in the arse,' said Aidan, 'you know that?'

'You would fucking love it,' said Jojo.

Then she got up and walked out of the room, looking over her shoulder at him. He followed her upstairs and grabbed hold of her from behind as she was going into Melody's room. It was a kind of a wrestle, half fight and half cuddle. She bit him while they were kissing and it fucking hurt, but he wrestled her down on the bed and they did it.

Afterwards they sat on the bed and shared one of Melody's Marlboro Lights. 'Not so small after all, eh?' he said, then went downstairs and got them a beer each. But when he got back upstairs she was brushing her hair and she gave him a stony look.

She took the beer and had a big gulp, and then started getting dressed. (Williams 2017: 149-150)

\section{Conclusion}

Through engaging closely with Grettis saga I was able to understand how saga style and structure relate to each other and to the historical context of their setting. Learning from saga writers cannot be a case of cherrypicking certain techniques and effects. Rather, it involves understanding how saga narrative, style, structure and context combine to produce a mature literary work. Meanwhile, rewriting the saga into a contemporary setting meant finding narrative equivalents for saga events, and re-imagining their consequences to make sense in a contemporary world. In turn this meant reflecting on societal values and structures in the two contexts and on how these shape events, lives and stories: in particular, the role of violence, the notion of the monstrous, and the treatment of gender and sexual violence. Though these specific lessons are peculiar to the rewriting of this saga, the project provides one model for writer-researchers interested in engaging with medieval literature. It shows that it is possible to move beyond the appropriation of tropes, setting and materials into an existing modern form (a process which treats sources as inert and disregards the writerly techniques and practices which produce them). Engaging respectfully and in detail with medieval writers and their practice means looking beyond the exotic 'other' of distant historical settings and materials, and instead seeking to learn how medieval styles, structures and processes can be used to extend, diversify and invigorate writing in our own time.

\section{Notes}


[1] The authorship of the saga is unknown; the standard text is that edited by Gudni Jónsson in the Íslenzk fornrit series (1936). I have no Icelandic and worked throughout from translations, particularly those by Denton Fox \& Hermann Pálsson (1974) and by Bernard Scudder (1997). All quotations are from Fox \& Hermann. return to text

[2] In the following discussion I am indebted to comments made on an earlier version of this paper by participants at the Leeds International Medieval Congress 2017. return to text

\section{Works cited}

Note: in accordance with Icelandic practice, Icelandic names are listed alphabetically by given name.

Andersson, TM \& WI Miller 1989 Law and Literature in Medieval Iceland: Ljósvetninga saga and Valla-Ljóts saga, Stanford University Press, Stanford return to text

Ármann Jakobsson 2011 'Beast and Man: Realism and the Occult in Egils saga', Scandinavian Studies 83, 1: 29-44 return to text

Bampi, M 2005 'Revisiting the past: P.O. Sundman's rewrite of Hrafnkels saga Freysgoda', in M Buzzoni \& M Bampi (eds) The Garden of Crossing Paths: The Manipulation and Rewriting of Medieval Texts, Università Ca' Foscari Venezia, Venice: 209-224 return to text

Burns, M 1991 'Echoes of William Morris's Icelandic Journals in J.R.R. Tolkien', Studies in Medievalism 3, 3: 367-373 return to text

Byock, J 1982 Feud in the Icelandic Saga, University of California Press, Berkeley return to text

Byock, J 1984 'Saga form, oral prehistory, and the Icelandic Social Context', New Literary History $16,1: 153-173$ return to text

Byock, J 2004 'Social memory and the sagas: The case of Egils saga', Scandinavian Studies 76, 3: 299-316 return to text

Clunies Ross, M 1997 'The intellectual complexion of the Icelandic Middle Ages: Towards a new profile of Old Icelandic saga literature', Scandinavian Studies 69, 4: 443-453 return to text

Clunies Ross, M 1998 Prolonged Echoes: Old Norse myths in medieval Northern society. Volume 2: The reception of Norse myths in medieval Iceland, Odense University Press, Odense return to text

Clunies Ross, M 2002 'Realism and the Fantastic in the Old Icelandic Sagas', Scandinavian Studies 74, 4: 443-454 return to text

Crawford, J 2010 Tattúinárdóla saga: If Star Wars Were an Icelandic Saga: https:/tattuinardoelasaga.wordpress.com/2010/03/01/tattuinardoela-saga-if-star-wars-were-anicelandic-saga/ (accessed 10/07/19) return to text

D’Arcy, J \& K Wolf 1987 'Sir Walter Scott and Eyrbyggja Saga', Studies in Scottish Literature 22, 1: http://scholarcommons.sc.edu/ssl/vol22/iss1/5 (accessed 08 March 2019) return to text

Fox, D \& Hermann Pálsson 1974 'Introduction', Grettir’s Saga, University of Toronto Press, Toronto return to text

Francis, M 2018 'Rewriting the Mabinogi', New Writing 15, 3: 311-321 return to text

Grettir's Saga 1974, D Fox \& Hermann Pálsson (trans), University of Toronto Press, Toronto return to text

Grettis saga Ásmundarsonar 1936 in Gudni Jónsson (ed), Íslenzk fornrit Vol 7, Hid Íslenzka fornritafélag, Reykjavík return to text 
Hall, A 2017 Útrásarvikingar! The literature of the 2008 Icelandic financial crisis, open access working paper, last edited 5 December 2017: https://www.academia.edu/35340298 (accessed 07 November 2018) return to text

Hall, A 2018 'Fornaldarsögur and financial crisis: Bjarni Bjarnason's Mannord', in M Driscoll et al (eds) The Legendary Legacy: Transmission and reception of the Fornaldarsögur Norourlanda, University Press of Southern Denmark, Odense, 351-376 return to text

Harris, J 1986 'Saga as historical novel', in J Lindow et al (eds) Structure and Meaning in Old Norse Literature: New approaches to textual analysis and literary criticism, Odense University Press, Odense, 187-219 return to text

Helgi Thorláksson 2007 'Historical Background: Iceland 870-1400', in R McTurk (ed) A Companion to Old Norse-Icelandic Literature and Culture, Blackwell, Oxford: 136-154 return to text

Hume, K 1984 Fantasy and Mimesis: Responses to Reality in Western Literature, Methuen, London return to text

Jackson, R 1981 Fantasy: The Literature of Subversion, Methuen, London return to text Jochens, J 1995 Women in Old Norse society, Cornell University Press, Ithaca return to text Jón Karl Helgason 1999 The Rewriting of Njáls saga: Translation, Ideology and Icelandic Sagas, Multilingual Matters, Clevedon

Jón Karl Helgason 2005 'Njáls saga as a novel: four aspects of rewriting', in M Buzzoni \& M Bampi (eds) The Garden of Crossing Paths: The Manipulation and Rewriting of Medieval Texts, Libreria Editrice Cafoscarina, Venice: 185-192 return to text

Jón Karl Helgason 2017 Echoes of Valhalla: The Afterlife of the Eddas and Sagas, Reaktion Books, London return to text

Kári Gíslason 2009 'Within and without family in the Icelandic sagas', Parergon 26, 1: 13-33 return to text

Laxness, H 2016 Wayward Heroes, P Roughton (trans), Archipelago Books, New York return to text

Ljungqvist, F 2015 'Rape in the Icelandic Sagas: An Insight in the Perceptions about Sexual Assaults on Women in the Old Norse World', Journal of Family History 40, 4: 431-447 return to text

McFarlane, H 2013 'Masculinity and Criminology: The Social Construction of Criminal Man', The Howard Journal 52, 3: 321-335 return to text

McGregor, R 1993 Per Olof Sundman and the Icelandic Sagas: A Study of Narrative Method, doctoral thesis, University of Otago, Dunedin NZ return to text

Nakadate, N 1999 Understanding Jane Smiley, University of South Carolina Press, Columbia SC return to text

Phelpstead, C 2007 'Size Matters: Penile Problems in Sagas of Icelanders', Exemplaria 19, 3: 420437 return to text

Phelpstead, C 2008 “"With chunks of poetry in between": The Lord of the Rings and Saga Poetics', Tolkein Studies 5: 23-38 return to text

Roberts, DJ 1961 Fire in the Ice, Little, Brown, Boston return to text

Scudder, B \& Örnólfur Thorsson 2005 'Introduction', The Saga of Grettir the Strong, Penguin Classics, London return to text

Smiley, J 1988 The Greenlanders, Fawcett Columbine, New York return to text 
Smiley, J 1999 'Shakespeare in Iceland', in M Novy (ed) Transforming Shakespeare:

Contemporary Women's Re-Visions in Literature and Performance, Macmillan, London: 159-180 return to text

Smiley, J 2000 'Preface', in Örnólfur Thorsson (ed), The Sagas of Icelanders: A Selection, Penguin, London: ix-xiv return to text

St Clair, G 1995 'An Overview of the Northern Influences on Tolkien's Works', Mythlore 80/Mallorn 30, The Tolkien Society and the Mythopoeic Press, Milton Keynes: 63-67 return to text

Stendhal, B 1981 'Per Olof Sundman on the Expedition of Truthtelling', World Literature Today 55, 2: 250-256 return to text

Sundman, PO 1970 The Expedition, M Sandbach (ed), Panther, London return to text

Sundman, PO 1977 Berättelsen om Såm, Norstedt, Stockholm return to text

'The Saga of Grettir the Strong' 1997 in Vidar Hreinsson et al (eds) The Complete Sagas of Icelanders Vol 2, B Scudder (trans), Leifur Eiríksson, Reykjavík: 49-191 return to text

Thórir Óskarsson 2007 'Rhetoric and Style', in R McTurk (ed) A Companion to Old NorseIcelandic Literature and Culture, Blackwell, Oxford: 354-371 return to text

Tulinius, T 2005 'Re-writing the contemporary sagas: How several modern novelists use Sturlunga saga', in M Buzzoni \& M Bampi (eds) The Garden of Crossing Paths: The Manipulation and Rewriting of Medieval Texts, Università Ca' Foscari Venezia, Venice: 193-208 return to text

Tulinius, T 2013 'Returning Fathers: Sagas, Novels, and the Uncanny', Scandinavian-Canadian Studies 21: 18-39 return to text

Vésteinn Ólason 1998 Dialogues with the Viking Age: Narration and Representation in the Sagas of the Icelanders, A Wawn (trans), Heimskringla, Reykjavik return to text

Warme, L 1984 Per Olof Sundman: Writer of the North, Greenwood Press, Westport CT return to text

Williams, T 2017 Nutcase, Salt, Cromer, Norfolk return to text

Tony Williams is Associate Professor in Creative Writing at Northumbria University. His novel NUTCASE adapts The Saga of Grettir the Strong into a contemporary setting. All the Bananas I've Never Eaten won best short story collection in the Saboteur Awards, while his poetry has been shortlisted for the Aldeburgh, Portico and Michael Murphy prizes, and has been a PBS Pamphlet Choice. He also works in collaboration with the film-maker Alan Fentiman.

\section{TEXT}

Vol 23 No 2 October 2019 http://www.textjournal.com.au General Editor: Nigel Krauth. Editors: Julienne van Loon \& Ross Watkins text@textjournal.com.au 
